Hosie, P. and Nankervis, A. 2016. A multidimensional measure of managers' contextual and task performance. Personnel Review. 45 (2): pp. 419-447. 


\title{
A multidimensional measure of managers' contextual and task performance
}

\begin{abstract}
Purpose - This paper reports the findings of an empirical study into managers' job performance. A new measure was developed from the literature to test and establish the multidimensional structure of managers' contextual and task performance.
\end{abstract}

Design/methodology/approach - Field ratings by executives explicitly and simultaneously measured both managers' contextual and task performance. A cross-sectional questionnaire was administered to a variety of public and third sector managers from a range of private, public, and third sector occupations residing in (Western) Australia. A purposive sample yielded a response rate of 32\%. Factor analysis was used to determine the items that constitute executives' perceptions of managers' performance using downward appraisal (i.e., by the person to whom a manager reports).

Findings - The construct 'managers' job performance' was found to be multidimensional; consisting of four distinct contextual factors (Following, Persisting, Helping, Endorsing) and a further four distinct task factors (Delegating, Monitoring, Technical, Influencing).

Originality/value - Performance appraisals of managers represent new items and factors that more accurately reflect the nature of the broader roles undertaken by managers, including transformative and ethical leadership. Findings from this study assist in establishing the structure for the subsequent appraisal of managers' contextual and task performance. Future researchers could test the applicability and replicability of this new instrument in more diverse industry contexts using confirmatory statistical analysis.

Keyword Manager, job, performance, leader, task, contextual, appraisal, field, empirical, multidimensional.

Paper type Research paper 


\section{Introduction}

Job performance is arguably the most important criterion variable in occupational, industrial and organizational psychology, and human resource management. Researchers have been attempting to construct accurate measures of job performance since the turn of the $20^{\text {th }}$ century. This quest was impelled by the imperative to effectively manage human capital to enhance organizational productivity and increase competitiveness (Boudreau and Ramstad 2009, Guest 2011). Yet, despite extensive research into the construct of job performance there is still no common framework for considering the underlying performance dimension requirements of jobs. Indeed, Campbell (1996, p. 11) concluded that the "search for reliable, uncontaminated, objective indicators that significantly reflect the ultimate criterion has been a failure."

After reviewing models of job performance (e.g., 'classical' general factor model, critical deficiency model), Campbell et al (1996) reaffirmed support for the multifactorial nature of job performance. Attempts to identify the one general factor capable of assessing job performance have been largely futile. Even proponents of the critical deficiency model, which attempts to identify a general factor of performance, have conceded that sub-factors may underlie a general factor of performance (Viswesvaran et al. 2005). Empirical support for a unidimensional model of managers' performance is correspondingly limited. A wealth of evidence exists to substantiate the generic, multidimensional and dynamic nature of managers' performance (Ployhart et al. 2003, Campbell 1996).

Few scholarly endeavours have received as much attention as the concept and construct of managers' performance (Dierdorff et al. 2009). According to Borman and Brush (1993), there have been calls for over 80 years for a more sophisticated articulation of managers' job performance (cited inTett et al. 2000). Despite appeals for investigations into a broad range of managerial roles, there have only been four comprehensive and credible meta-studies into the role requirements of managers over the last 20 years (Tett et al. 2000, Borman and Brush 1993, Dierdorff et al. 2009, Conway 1999). Scholars need to make more headway on important issues surrounding the construct specificity of managerial performance. Such dimensions need to be behaviourally-based, resulting from many critical incident and job activity statements that reflect what managers actually do, as opposed to what others believe they do. Consequently, measuring and utilising manager's performance remains highly problematic, despite its significance to the overall management of human capital within organizations.

Fayol's $(1916,1949)$ classic work represents the beginnings of the endeavour to identify what managers do (planning, commanding, coordinating, and controlling) and how these managerial activities and dimensions contribute to organizational effectiveness. Most of the enduring perspectives on managers' behaviours were derived from extensions of Fayol's work (Tornow and Pinto 1976, Hemphill 1959, Williams 1956, Yukl 1998, Steers 1975, Flanagan 1954, Flanagan 1951, Kotter 1982, Shetty 1982, Mintzberg 1973, Campbell et al. 1970).

Two streams of research into the nature of managerial work, the unitarist and the functionalist, have emerged since the 1960s (Martinko and Gardner 1990, Luthans et al. 1988, Luthans et al. 1985, Boyatzis 1982, Morse and Wagner 1978). From the unitarist standpoint, managers are viewed from a growth perspective by the functions, behaviours, roles, and decisions they make (Borman and Brush 1993). Most of the research into managers' work has focused on managerial activities and behaviours, rather than outputs of the relationship "between what managers do and what they achieve" (Stewart 1989, p. 2).

The functionalist perspective emphasises the measurement of managers' objective output as an indicator of organizational effectiveness. Quinn et al. (1996) identified productivity, profit, stability, continuity, commitment, cohesion, morale, adaptability and external support as important criteria for influencing organizational effectiveness. Using this approach, job appraisal is conceived as an integral part of a broader performance management system. Functionalism, with its view of reality as being an objective, unified and readily observable 
entity (Model 2005), has been criticised for failing to provide a comprehensive perspective of organizational phenomena (Gioia and Pitre 1990, Rao and Pasmore 1989, Morgan and Smircich 1980). Many scholars of social phenomena subscribe to a positivist perspective of organizations (Gioia and Pitre 1990, Burrell and Morgan 1979). As such, functionalism assumes that managerial effectiveness is quantifiable, a social constructivist perspective, based on the assumption that organizational phenomena are socially constructed (Cammock et al. 1995).

Integrating the functionalist (task performance) and social constructivist (contextual performance) perspectives offers a more holistic conceptualisation of managers' performance. A contemporary social constructivist perspective of managers' performance is informed by theories of: motivation (McClelland 1985); human needs (Johnston 1979); expectancy (Vroom 1964); job performance (Motowidlo et al. 1997); individual differences (Borman and Motowidlo 1993, Motowidlo et al. 1997); attribution (De Vader et al. 1986); self-efficacy (Bandura 1977); social cognition (Bandura 1986); work adjustment (Dawis and Lofquist 1984, Dawis and Lofquist 1993); contingency (Jones 1995, Pfeffer 1982); and competence (Guion 1991). Thus, functionalism is a view of managers' performance located within an interpretative paradigm (Burrell and Morgan 1979).

Organizational culture's effect on performance can be seen through either functionalist or interpretivist approaches (Burrell and Morgan 1979). A discernible shift away from a normative or prescriptive view (i.e., how managers should manage) is noticeable in organizations with an interpretivist perspective of managers' performance (i.e., the functions, behaviours and roles of managers, including their leadership styles and behaviours) (Cammock et al. 1995). Together with this trend there is an increased emphasis on outputs, rather than just behaviours, which should be included in measures of managers' performance that are subsequently linked to organizational outcomes (Robertson et al. 2000). This reflects contemporary demands that all human resource management (HRM) strategies and processes, especially managing the performance of managers, should be aligned with and focused on organizational effectiveness (Guest 2011, Nankervis et al. 2013).

In this interpretivist conceptualisation, managerial job performance measures focus on using the best available 'objective' indicators of an individual's achievements. These studies have conceived managers' job performance to be a construct that comprises mainly task performance (Motowidlo and Schmit 1999, Borman and Brush 1993). Indications are emerging from the literature to suggest that managers' contextual performance is also an important contributor to organizational effectiveness (Butler and McEvoy 2012, Nankervis et al. 2013). However, as Dierdorff, Rubin and Morgeson (2009) observed, few associated empirical research studies have yet been undertaken to simultaneously measure contextual and task dimensions of managers' performance. Similarly, no research to date has explicitly and simultaneously measured both managers contextual and task performance using downward field ratings.

This study explicitly seeks to address gaps in the existing research by identifying the dimensions that underlie managers' performance in organizations. A series of interrelated research questions were derived from the contemporary literature to ascertain if managers' performance was unidimensional or multidimensional. If managers' performance consists of multiple dimensions, then shared meaning may be attributed to the distinct dimensions of managers' contextual and task performance. Hence, it will be possible to measure multiple performance dimensions capable of identifying the most reliable indicators of managers' contextual and task performance. Finally, it is determined if the construct managers' job performance can be generalized across different occupational groups.

A new empirical measure was developed from the literature to test and establish the multidimensional structure of managers' contextual and task performance using factor 
analysis. Item used to measure managers' contextual and task performance scales were sourced from the literature. A sophisticated understanding of what constitutes managers' job performance emerged from an analysis of the combination of contextual and task behaviours. A series of research questions derived from the literature was used to decide what constitutes executives' perceptions of managers' job performance using downward appraisal ratings by executives (i.e., by the person to whom a manager reports). The managers' job performance construct was found to consist of eight dimensions, incorporating four contextual dimensions (Following, Persisting, Helping, Endorsing) and four task dimensions (Delegating, Technical, Monitoring, Influencing). The construct 'managers' job performance' was found to consist of a comprehensive range of contextual and task factors, and related items, that explain the roles managers undertake, including some forms of leadership.

We begin by defining the terms essential to this study with a review of the theoretical foundations of managers' contextual and task performance. This is followed by a summary of the main findings and general conclusions, and discussion of theoretical and practical implications of this research for organizations and HRM professionals.

\section{Literature review \\ Definitions}

Definitions of managers' job performance have evolved from a fragmented literature. Karpin (1995, pp. 14, 63) offered a definition of a manager based on work by Quinn (1992) and Boyatzis (1982), as an "An individual who achieves enterprise goals through the work of others ... Managers are responsible for the control or direction of people, a department or an organization.” In this conceptualisation, a manager's contribution represents a consolidated value to an organization. Managers operate within the context of organizations by planning, organising, coordinating and supervising; functions that indirectly contribute to the efficient and effective operation and output of an organization. To be effective, there needs to be a congruence between managers' performance and organizational goals (Hart and Quinn 1993). A consolidated definition from the literature of managers' performance is offered by Hosie, Sevastos and Cooper (2007, p. 75) as "the recent net contribution value to organizational effectiveness and goals, attained in conjunction with people, determined by events under managers' control, in a particular environment."

Managerial and leadership behaviour is complex to capture and articulate. From a comprehensive review of the literature, Stogdill (1974, p. 259) concluded that "there are almost as many definitions of leadership as there are persons who have attempted to define the concept.” Apart from the process of influencing others, these definitions do not share much in common. Notwithstanding considerable efforts, no compelling distinction between leaders and managers has emerged. There is still no widely accepted theory of leadership. Despite continuous research, since 1900 to identify what constitutes a good leader, there is no credible knowledge about what constitutes the unique qualities that good leaders possess. Hence, the distinction between managers and leaders is somewhat arbitrary in contemporary organizations.

Management and leadership roles overlap, as "most managers show some leadership skills, while most leaders find themselves managing at times” (Karpin 1995, p. 1210). Moreover, management is characterised by Bennis and Nanus (1985, p. 21) as "doing things right [process]" while leadership is about "doing the right thing [content]." For Bennis and Nanus (1985, p. 21), leadership is morally purposive with an ethical dimension, such that "Managers cannot be successful without being good leaders, and leaders cannot be successful without being good managers ... Effective management and leadership are inseparable” (Carlopio et al. 1995, p. 12). However, this should not be taken to mean that leadership and management are identical, as there is disagreement in the literature about the extent of overlap in the respective 
roles. Likewise the distinction between managers and employees is blurred as managers are also likely to be employees.

Employees usually undertake work delegated and supervised by managers. Employees can be categorised as either 'regular' or 'contingent' employees. Regular employees “denote people in traditional, ongoing, and open-ended employment relationships" (Rousseau 1995, cited in Dyne and Ang 1998, p. 692). In contrast, contingent work refers to "Any job in which an individual does not have an explicit or implicit contract for long-term employment or one in which the minimum hours worked can vary in a non-systematic manner" (Polivka and Nardone 1989, p.11). According to De Cuyper (2008), contingent work is described internationally as temporary, fixed-term, non-permanent or casual employment. In Canada and the USA, contingent work, as distinct from other forms of alternative or non-standard work, is characterized by the USA Bureau of Labour Statistics as "any job in which an individual does not have an explicit or implicit contract for long-term employment or one in which the minimum hours worked can vary in a nonsystematic manner." (Polivka and Nardone 1989, p. 11). Permanent part-time employees and independent contractors are excluded from this definition, when they determine their own hours of work, are paid by the task/s, and perform their work off-site. Counter-intuitively, contingent professional employees have exhibited nonsignificant results, or positive Organizational Citizenship Behavior and affective commitment relationships with organisations in contrast to regular employees (Dyne and Ang 1998, Pearce 1993).

\section{Managers' contextual and task job performance}

Two types of managerial job performance-contextual and task-have been identified by Borman and Motowidlo (1997, 1993), Motowidlo, Borman and Schmit (1997), Dierdorff, Rubin and Morgeson (2009), and Conway (1999). Task performance was defined by Borman and Motowidlo (1993, p. 72) as the "effectiveness with which job incumbents perform activities that contribute to its technical core either by directly implementing a part of its technological process, or by providing it with needed materials or services”. Further. task performance was considered by Organ and Paine (1999, p. 375) to be a "part and parcel of the workflow that transforms inputs of energy, information and materials into outputs in the form of goods and services to the external constituency”. Task activities typically vary across different jobs but contextual activities are common to many jobs (Motowidlo and Schmit 1999, Borman and Motowidlo 1993). In contrast, task behaviours are role-prescribed where contextual behaviours are not usually explicitly stated as a formal organizational obligation; incumbents must demonstrate proficiency in performing tasks in exchange for rewards. Using multi-trait and multi-rater methods, Conway (1999) provided evidence of a distinction between task and contextual performance; a difference that was more pronounced for non-managerial than managerial jobs.

\section{Contextual performance and Organizational Citizenship Behavior}

Conceptions of, and attempts, to measure Organizational Citizenship Behavior preceded those of the related construct, contextual performance. Initially Organ (1988, p. 4) defined Organizational Citizenship Behavior formally as "individual behavior that is discretionary, not directly or explicitly recognized by the formal reward system, and that in the aggregate promotes the effective functioning of the organization.” There are conceptual and ambiguity issues related to Organizational Citizenship Behavior definitions, primarily related to discretionary and non-rewarded behavior. Borman and Motowidlo (1993) defined contextual performance, as "contributions to the maintenance and enhancement of the social and psychological context that supports task performance” (Organ 1997, p. 91).

Further, Borman and Motowidlo (1993) considered contextual performance as "a set of 
interpersonal and volitional behaviors that support the social and motivational context in which organizational work is accomplished." As Organ (1997, p. 90) observed, "What is different from Organizational Citizenship Behavior is that contextual performance as defined does not require that the behavior be extra-role (discretionary) nor that it be non- rewarded. The defining quality is that it be 'non-task', or more to the point, that it contribute to the maintenance and/or enhancement of the context of work." Elements of contextual performance have been deduced from: Extra-Role Behavior (Van Dyne et al. 1995). Organ (1997) eventually settled on a definition of contextual performance that is essentially the same as for Organizational Citizenship Behavior (Motowidlo 2000). As such, the terms and intent of Organizational Citizenship Behavior and contextual performance are interchangeable and may be referred to generically as ‘citizenship’ behavior.

Discretionary work behaviours may be conceived as contextual performance, an aspect of which is the freedom to act according to one's judgement. Contextual performance was considered by Organ and Paine (1999) to represent the psychological linkages between people, represented by discretionary forms of contributions to the organization that have uncertain or indirect rewards compared to task performance. Contextual performance reinforces the linkages amongst employees, and thereby sustains and enhances the collective character of organizations (Organ and Paine 1999). Conversely, contextual activities require discretionary behaviors, which have interpersonal and motivational implications. Above all, contextual acts by managers are performed beyond what is formally expected. Notably, management work roles occur in diverse work contexts, can exert a profound influence on what work role requirements are more or less important, and are a key component of performance management systems (Dierdorff et al. 2009). These behaviors may sometimes be rewarded, but they are unlikely to be explicitly incorporated into formal job requirements, with the notable exception of 'leading edge' employers of choice.

\section{Differentiating between task and contextual performance}

Both contextual and task domains of performance contribute to the accomplishment of organizational goals, but through different mechanisms. Task and contextual performance has been distinguished by three key assumptions: (1) activities associated with contextual performance are similar across jobs, whereas actions associated with task performance will vary between jobs; (2) contextual performance is linked to personality and motivation; while task performance is related to ability; (3) contextual performance is discretionary and extrarole, whereas task performance is prescribed and comprised of in-role behavior (Borman and Motowidlo 1997, Motowidlo and Schmit 1999, Johnson 2001, Conway 1999).

Borman and Schmit (1997) distinguished between contextual and task performance as illustrated in Figure 1. 
Figure 1: Theory of Individual Differences in contextual and task performance
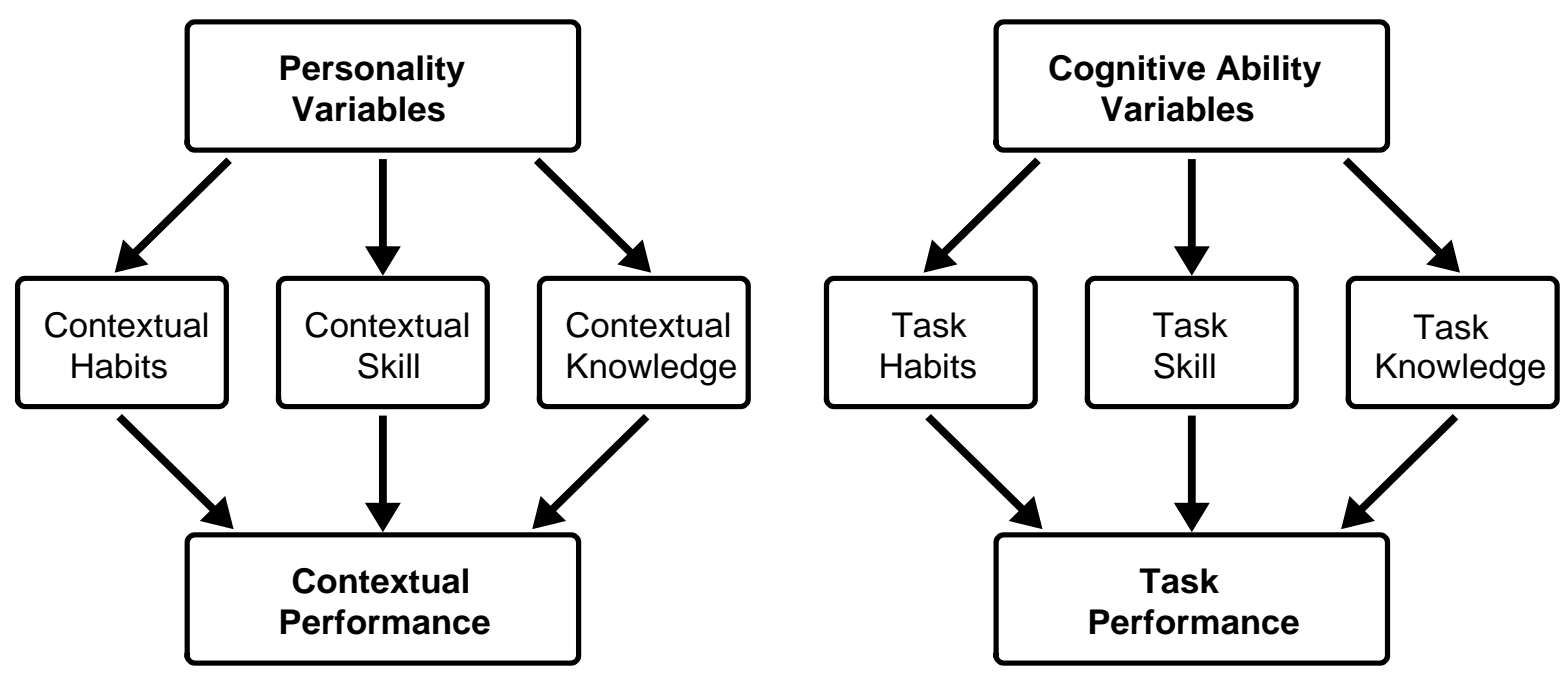

Source: Motowidlo, Borman \& Schmit (1997, p. 79).

Managers' performance was separated into contextual and task categories by Motowidlo, Borman and Schmit (1997) to identify dimensions that constitute performance. Contextual performance has been associated with personality, whilst task performance was associated with cognitive ability (Motowidlo et al. 1997). Motowidlo and Van Scotter (1994) confirmed MacKenzie et al.'s (1991) findings that contextual and task performance are determined by different predictors. Cognitive ability and personality are argued by Motowidlo, Borman and Schmit (1997) to be mediated by knowledge, skills and work habits.

Task performance varies across and differentiates jobs, whereas contextual performance is common to most jobs. Task performance is about the proficiency with which activities are accomplished. Thus, variability across employees on task performance is logically attributable to differences in tasks undertaken as well as individual knowledge, skills, and ability; while contextual performance "has the effect of maintaining the broader organizational, social and psychological environment in which the technical core must function” (Motowidlo et al. 1997, p. 75). Thus, contextual performance is a diverse multidimensional concept, rather than a single set of uniform behaviors (Van Dyne and Le Pine 1998). Contextual performance is less a function of managers' levels of proficiency than choice, and is therefore related more to differences in individual dispositions and personalities, by indicated in the Theory of Individual Differences, as its applications are likely to vary across organizations.

\section{Contextual performance and its links to organizational effectiveness}

Scholars from the different traditions agree that patterns of behavior outside formal job task requirements are important for human performance, organizational effectiveness and subsequent profitability (Borman and Motowidlo 1997). Contextual behaviors are claimed by Organ (1997) to contribute towards the maintenance and enhancement of the social and psychological climate that supports organizational technical production systems. There is also evidence to suggest that contextual performance does improve the effectiveness of work groups and organizations as a whole (Podsakoff and MacKenzie 1997, Podsakoff et al. 1997). The 'culture and change agent' role of HRM professionals proposed by some contemporary researchers (Ulrich et al. 2013) encompasses both the identification of contextual characteristics and the incorporation of appropriate performance measures in the design of effective managerial performance systems. 
When aggregated over time and people, Organizational Citizenship Behavior is postulated to enhance organizational effectiveness (Karambayya 1990, Organ 1988). Also, a tentative link between Organizational Citizenship Behavior and organizational effectiveness has been established by Podsakoff and MacKenzie (1997). Contextual aspects of managers' jobs are potentially substantial and critical to an organization's productivity (Organ and Paine 1999). But evidence is needed to establish a closer link between individual managers' performance on contextual dimensions and organizational effectiveness.

All aspects of contextual performance emphasise behaviors that involve cooperation and helping others in the organization, and behaviors that ultimately contribute to organizational effectiveness. For this reason, researchers continue to investigate the antecedents for these cooperative behaviors. These contextual work activities were derived from conceptual frameworks that describe the organizational behavior domains considered necessary for attaining organizational effectiveness. Neal and Griffin (1999) drew on Borman and Motowidlo's (1993) conceptualisation of task and contextual performance to create a model of the antecedents, determinants and components of performance, integrating both task and contextual performance. As provided in Figure 2, these were intended to synchronise interventions with existing mechanisms and thereby identify and remove key situational constraints in the workplace. These components of performance represent the behaviors that individual managers exhibit at work.

Figure 2: Antecedents, determinants and components of performance

Antecedents

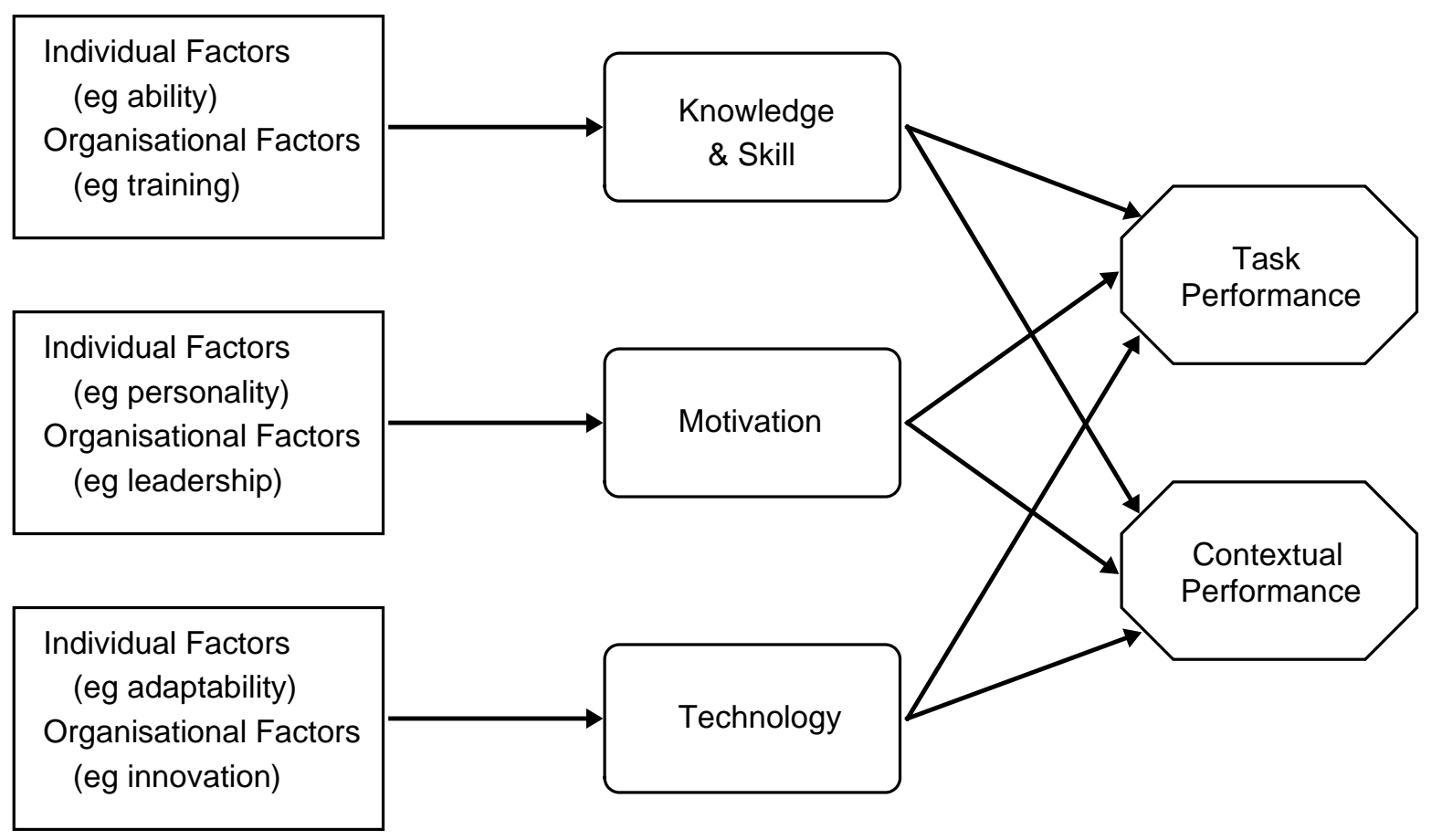

Source: Neal \& Griffin (1999, p. 48).

As indicated in Figure 2, overall job performance is a function of both perceptions of contextual actions, and the performance of task activities. Task activities normally vary across different jobs but contextual activities are reported to be common to many jobs (Motowidlo and Schmit 1999, Borman and Motowidlo 1993). These activities are conceived of as role-prescribed, whereas contextual behaviors are not usually explicitly stated as a formal organizational 
obligation.

A convergence of theoretical and empirical findings is emerging amongst scholars from different research traditions to suggest that other patterns of behavior, besides formal job requirements, are critical for organizational effectiveness (Borman and Motowidlo 1993). As such, individuals contribute to organizational effectiveness in ways that go beyond the activities that comprise their 'job' (Borman and Motowidlo 1993, p. 71). Managers' contributions to organizational effectiveness often exceed the role-specific tasks they perform, and either assist or impede the achievement of organizational goals. These findings encourage further exploration of the contextual performance construct.

\section{Mega-dimensions of managers' performance}

All meta-analysis of major investigations into managers' performance dimensions refer to, or are dependent on seminal work by Boyatzis (1982), who identified the personal characteristics linked with effective managerial performance. Boyatzis's (1982) Model of Effective Job Performance is seminal to models of management competencies seeking to assess performance and provide role clarification.

Figure 3: Model of Effective Performance

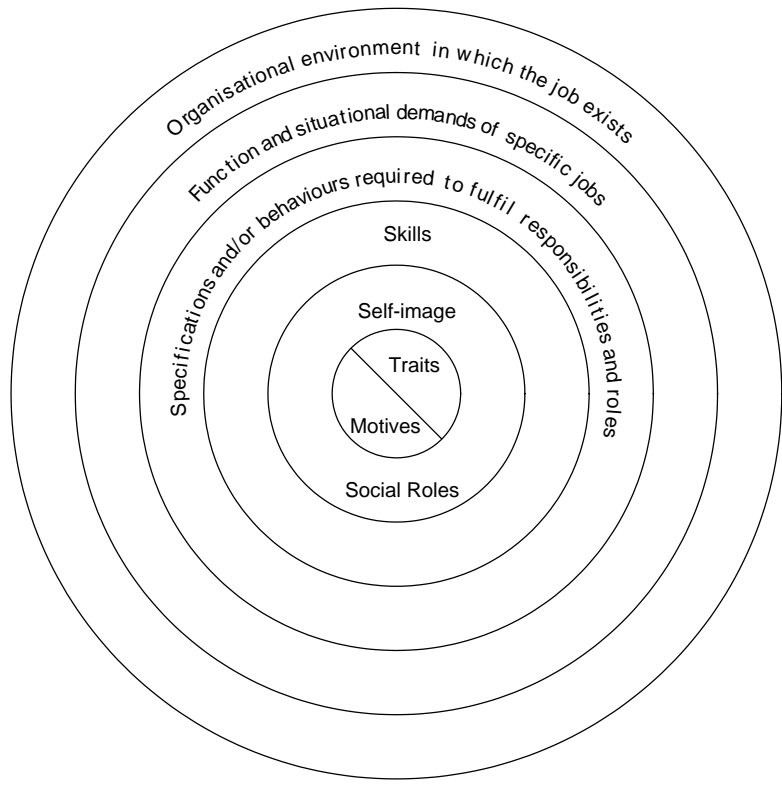

Source: Adapted from Boyatzis (1982).

As noted earlier, there is an absence of contemporary and robust measurement instruments of managerial performance. This is partly a function of the methodologies employed to study managers, as managerial performance dimensions mostly derived from questionnaires and focus groups. In contrast, critical incident studies are useful for differentiating between behaviorally effective and ineffective managers and identifying performance-related dimensions. Consistent with other prominent researchers in the area (cf. Murphy 1990), Borman and Brush (1993, p. 603) viewed the "bandwidth of all job performance measures to be broad and advocate multiple and complex predictors to map the criterion space”. This metaanalysis of managers' performance was derived from behaviourally-based critical incidents and job activity statements. By integrating multiple dimensions, Borman and Brush’s (1993) and Borman and Motowidlo's (1997) taxonomies have provided a more comprehensive view of the dimensionality underlying managerial performance. 
By summarising the behavioral performance requirements of managers' jobs, Borman and Brush (1993) satisfied Campbell's (1991) challenge to use a broad sample of managerial jobs in order to identify core dimensions and to compare different managerial jobs. These megadimensions represent a consensus of many of the behavioral dimensions representing managers' jobs in a wide range of organizations, which equate to task performance. Borman and Brush's (1993) mega-dimensions were derived from data in a range of management jobs, providing a useful benchmark of categories to compare the dimensions from studies of managers' performance conducted in other organizations. This taxonomy consolidates what is known about the domains influencing managers' performance. This meta-analysis, as opposed to other contemporary meta-studies, were in a form suitable for developing into an instrument to measure managers' contextual and task performance.

Borman and Brush's (1993) meta-analysis and Borman and Motowidlo's (1997) taxonomies represent a comprehensive and rigorous taxonomy of the tasks that managers perform. There was a strong case for developing an instrument to measure both managers' contextual and task performance based on Borman and Brush's (1993), and Borman and Motowidlo's (1997) taxonomies. Conceptual indicators, and emerging empirical evidence, suggest that the contextual performance and task performance domains are distinct. Notably, contextual behaviors may contribute to organizational effectiveness, if maintained consistently over time and across individuals (Podsakoff and MacKenzie 1997, Borman and Brush 1993). How contextual performance contributes to organizations' effectiveness, is of particular relevance to these domains of managers' performance, and should therefore be incorporated into appraisals of their performance.

In summary, managers' job performance is conceived and explained in the literature as comprising both contextual and task performance, although these dimensions are not mutually exclusive. Managers' contextual performance is an aspect of job behavior, besides formal job requirements, that contributes to organizational effectiveness. Any instrument designed to measure managers' performance should incorporate items designed to measure both contextual and task components. Borman and Brush's 18 mega-dimension taxonomy of managers' contextual and task performance, provided a basis for the development of an instrument to measure managers' performance supported by the literature. These dimensions are representative samples of the domain of managers' performance.

\section{Methodology}

An empirical methodology was used to develop a new measure of managers' performance. The next section describes the process used to inform the research questions described earlier.

\section{Sample}

Several methods were used to recruit participants into this study. A self-administered questionnaire was used to collect the data, a common method for collecting survey data to reach a geographically dispersed sample at a relatively low cost (Zikmund 2002). Proximity and the willingness of organizations to be involved in the study was a practical consideration. Organizations were selected by distributing a letter of invitation to be involved in this study. The letter was received by, or referred to, each organization's Human Resource Department, or the equivalent. In most cases, the respective Human Resources Department conferred with the head of the organization before agreeing or declining to become involved.

Executives' downward appraisal (by the person to whom the managers' report) were used to simultaneously assess managers' individual performance as they were deemed more accurate than self-report. Performance ratings by supervisors is the most common form of job appraisal (Aamodt 2013). An estimated 90 percent of performance ratings is conducted by supervisors (Bernardin and Beatty 1984). Self-ratings of contextual performance invariably result in 
spuriously high correlations amongst performance variables that is confounded by common method variance (Organ and Ryan 1995).

Private, public and third sector ${ }^{1}$ managers in (Western) Australia constituted the target population. Organizations were selected from a variety of industries for inclusion in this study to ensure that the sample was representative of managerial jobs. Consistent with the sample, the respondents resembled a purposive sample (Zikmund 2002). Analyses of the sample characteristics indicated minimal differences between the demographics of the managers in the multi-sample. The majority of respondents were middle-aged married males with a mean age of 44.67 years, who had worked for 11.26 years as a manager, and 6.01 years with their current organization. A substantial proportion of managers (86.6\%) reported directly supervising an average of 11 employees. The variety of organizations and industries sampled operates in favour of generalizability and representativeness of the data. A total of 502 questionnaires were returned of the 1,552 distributed, for a total response rate (32\%) of 200 'useable pairs' of questionnaires.

\section{Methods}

The following decision rules were used to determine the appropriate clusters of variables to form the basis of a correlation matrix. A scree test was used to assist in deciding the eventual factor solution. Schweizer (1992) recommended this technique for detecting structures with discernible intercorrelations between variables. Eigenvalues were compared with Catell's scree plot to determine the numbers of factors to retain. Cronbach's alpha coefficients were used to calculate internal scale reliability (Price and Mueller 1986, Cronbach 1984). Coefficients were calculated for each scale and subscale derived from the questionnaire, to decide which items to delete, modify, and to check for congruence with the underlying dimensions. An internal reliability $\leq .7$ is acceptable for most psychological scales, which may be reduced to $\leq .6$ in a factor analysis (Hair et al. 1995). However, values $\leq .5$ are usually considered unacceptable (Cronbach 1984).

Factor analysis was conducted before modifying or deleting redundant performance items to determine the items that formed the factors of executives' perceptions of managers' performance. Each scale, subscale and item was separately analysed for communality, eigenvalue, percentage of variance, and cumulative variance. Before conducting the Maximum Likelihood Estimation factor analysis, the distributions for each of the variables were examined for general normality, for the presence of outliers and errors in coding, and for missing data.

Factor analysis is appropriate for deriving dimensions for theoretical purposes that are uncontaminated by unique or error variance (Tabachnick and Fidell 2001). Therefore, factor analysis was used to identify latent variables (common factors) that accounted for correlations among measured variables. Eigenvalues were used to determine the number of factors present. A Direct Oblimin rotation (as opposed to an orthogonal rotation) more realistically portrays correlated data and is suitable for interpreting the rotated solution, since it "provides a more accurate representation of how constructs are likely to be related to one another" (Fabrigar et al. 1999, p. 282). A Direct Oblimin solution provided a more meaningful result for this data because differences between high and low loadings are more readily interpretable in the pattern matrix. Oblique rotations more accurately represent the clustering of variables, because they are theoretically related to the underlying dimensions and show the magnitude of factor interrelations (Hair et al. 1995).

1 Third Sector refers to private incorporated organisations receiving private, Commonwealth and/or State Government funding. 


\section{Data analysis}

This section reports on the results obtained to determine the acceptable measures for the hypothesised measures of managers' performance. As mentioned earlier, rated performance of managers has previously been conceived of as a unidimensional construct. This section tests whether there were more dimensions to performance. Contextual and task dimensions were assumed to constitute managers' performance. The initial factor structure was determined by the executives' ratings of managers' performance using the total sample $(n=200)$.

Different statistical assumptions were applied to contextual and task performance scales, due to the theoretical structure of the factors, the source of variables, and the ratio of variablesto-cases. Pure measures were essential to test whether contextual and task performance factors were distinct dimensions. A first-order factor analysis was used to explain the majority of variance. An a priori 5-factor model was predicted for the 22-indicators comprising the contextual performance scale, and 75-indicators were predicted for the task performance scale.

Sample size, alpha and effect size were all analysed concurrently to achieve a threshold of $80 \%$ statistical power. However, factor analysis is particularly susceptible to sample size effects (Hinkin 1995). Some 200 responses of managers' performance were used to maximise statistical reliability and power. Clearly, the number of indicators (97) relative to the subsample size (200) was going to result in an 'overfitting' of the data, a good fit to the sample that is not generalizable to the population (Tabachnick and Fidell 2001). Therefore, the subsample for the factor analysis was split into those variables predicted to load separately onto the contextual and task dimensions, which were evaluated separately.

Multiple and redundant scales in multivariate analysis increases the potential for error in the data, especially when using a small sample. There was a need to undertake theoretical exclusion and empirical data reduction of selected scales. Hinkin (1995, p. 975)advice was adopted as the guiding principle for examining the scale properties, so the "Rationale for the retention and deletion of variables was clearly linked both theoretically and empirically." The most appropriate scales were both theoretically and empirically comparable. Only the scales and variables needed to test the dimensions were retained. Tabachnick and Fidell (2001) and Hair et al. (1995) both considered that a ratio of 10 cases per factor was acceptable. As noted earlier, at least three variables are needed per dimension to define a construct and were retained for analysis. The most parsimonious solution, consistent with the theoretical taxonomy, was sought for both contextual and task performance scales.

Judicious empirical and theoretical criteria were used to trim the scales to ascertain the number of predicted factors. Over half of the total variance is usually accounted for by the first four components of a factor solution (Hair et al. 1995, Tabachnick and Fidell 2001). As indicated earlier, an oblique rotation was considered appropriate because the factor correlation matrix indicated a moderate correlation between the first five factors. It is worth noting that factor analyses has a tendency to produce too many dimensions for a clear congruence with predicted definitions and constructs.

A factor analysis was used to indicate the most important dimensions of managers' performance in order to explain and test the logical and statistical properties of the managers' performance data. This established the independence of the managers' performance measures, which contained overlapping and redundant variables. The factor analysis established which variables loaded strongly on single factors and the reliability of observed variables was confirmed, using measures such as communalities and loadings. Indicators with the highest loading were retained. Variables that cross-loaded with measures intended to be distinctive were removed.

Invariably, the last factors extracted do not explain enough variance to be useful. These variables were the least representative of the domain(s) of interest. To identify whether variables cross-loaded on other factors, $\mathrm{a} \leq .40$ cut-off was used for the correlation matrix to 
produce relatively pure indicators. Variables that significantly cross-loaded $(\leq .40)$ on other factors were eliminated. For this type of study, Hair et al. (1995) recommended the construct reliability of variables loading should exceed $\geq .70$ to extract a total value variance of $\geq .50$ for each construct. These criteria were used as guidelines for eliminating variables that did not contribute adequate variance to the solution, unless they were theoretically congruent with the study. Indicators that met all of these criteria were retained.

Bartlett's test of sphericity was used to determine whether the correlation matrix differed from the identity matrix (Bartlett 1950). All significant values were $\geq .05$. Bartlett's test of sphericity is recommended at the lower bound of a matrix because it is sensitive and highly dependent on sample size (Tabachnick and Fidell 2001). A more sophisticated test of factorability, the Kaiser-Meyer-Olkin measure, was used to determine sampling adequacy (Tabachnick and Fidell 1996). A Kaiser-Meyer-Olkin measure of $\geq .6$ ensured factorability. Both contextual and task performance scales met this value requirement.

Communalities were calculated to measure how much variation in one variable could be explained by variation in all other variables included in the analysis. Variables with communalities $\geq .5$ usually do not provide sufficient explanation of the variance, and were mostly excluded from further analysis. Low communalities suggest that a variable may not have enough in common with any of the other variables and should be deleted from the analysis (Tabachnick and Fidell 1996, Holmes-Smith 1998). All variables exceeded a communality of $\geq .50$, suggesting that none of the variables should be eliminated using this technique.

After the number of factors and associated loadings were identified, it was determined whether the scales were related to each other in order to establish the factorability of the correlation matrix. The correlation matrix exceeded the coefficient of .32 (Kim and Mueller 1978b, Kim and Mueller 1978a, Kline 1994) in both correlation matrices, which suggested that the variables may be useable in a factor analysis (Tabachnick and Fidell 2001)..

\section{Research findings}

Contextual performance analysis

Using eigenvalues for establishing the number of factors is most reliable when the number of items was between 2-50 (Hair et al. 1995). With 22-indicators, the contextual performance scale was expected to produce a reliable number of factors. When developing new univariate subscales, Hair et al. (1995) recommended using a minimum of two indicators for established scales and 3-5 for untested scales. Contextual performance variables were predicted to indicate accurate eigenvalues, because these indicators were within the range of 20-55 indicators, and had already been used in published studies. In this situation, removing too many indicators from the factor matrix would have resulted in a reduction in the alpha coefficient of the scale.

A small sample is best analysed by reducing the number of indicators. Items were compared to establish those indicators that contributed to parsimony, possessed a simple structure, and were consistent with the predictions from which the scale was developed (Borman and Motowidlo 1997). Factor loadings of $\geq .50$ were acceptable for contextual performance, as they were based on indicators derived from previous studies into Organizational Citizenship Behavior.

Inspection of the scree plot (Figure 4) and pattern matrix (Table 1) indicated that the a priori five factor structure from the initial iteration of the variables was consistent with the literature on contextual performance. Five factors were indicated in the initial factor matrix rotation. Twelve of the indicators loaded unidimensionally on the predicted subscales. Ten of the 22 indicators exhibited low or complex loadings on the predicted factors. Indicators were progressively deleted until the most parsimonious solution was achieved that explained the most amount of variance consistent with the predicted structure.

Competing factor structures were examined, but none accounted for more variance, or 
resulted in higher subscale alphas or loadings of indicator on factors, than the solution given in Table 1. Grouping suggested by Borman and Motowidlo's (1997) taxonomy was maintained, with the exception of the Volunteering factor (not formally part of own job) which failed to form a distinct factor. Four indicators that loaded on the Volunteering factor and two on the Helping factor were deleted, because their factor loadings failed to attain the $\geq .50$ loading required for practical significance. The slope of the plot line falls dramatically after the fourth factor and before the fifth factor is extracted, indicating the presence of four not five factors. A major commensurate drop in total variance of the initial eigenvalues (from factor 4's eigenvalue of 1.171 to factor 5's Eigenvalue of .687) was evident between factors 4-5. The cumulative percentage of variance explained by factors $1-4$ was $73.087 \%$ (see Figure 4 ).

Convergent validity helps to establish construct validity when using two different measurement procedures and research methods (e.g., participant observation and a survey) to collect data about a construct (e.g., task performance). This does not seem to be relevant to this study as only one source of rating of managers is reported (the managers' direct report). Convergent validity needs to first be established before testing for divergent validity. On face value factor I (Following) may appear to be related to 'commitment' (or any number of possible names) but these factors have been specified a priori to be consistent with the relevant literature (Borman and Brush 1993, Borman and Motowidlo 1997, Motowidlo et al. 1997).

Figure 4: Contextual performance: Scree plot $(n=200)$

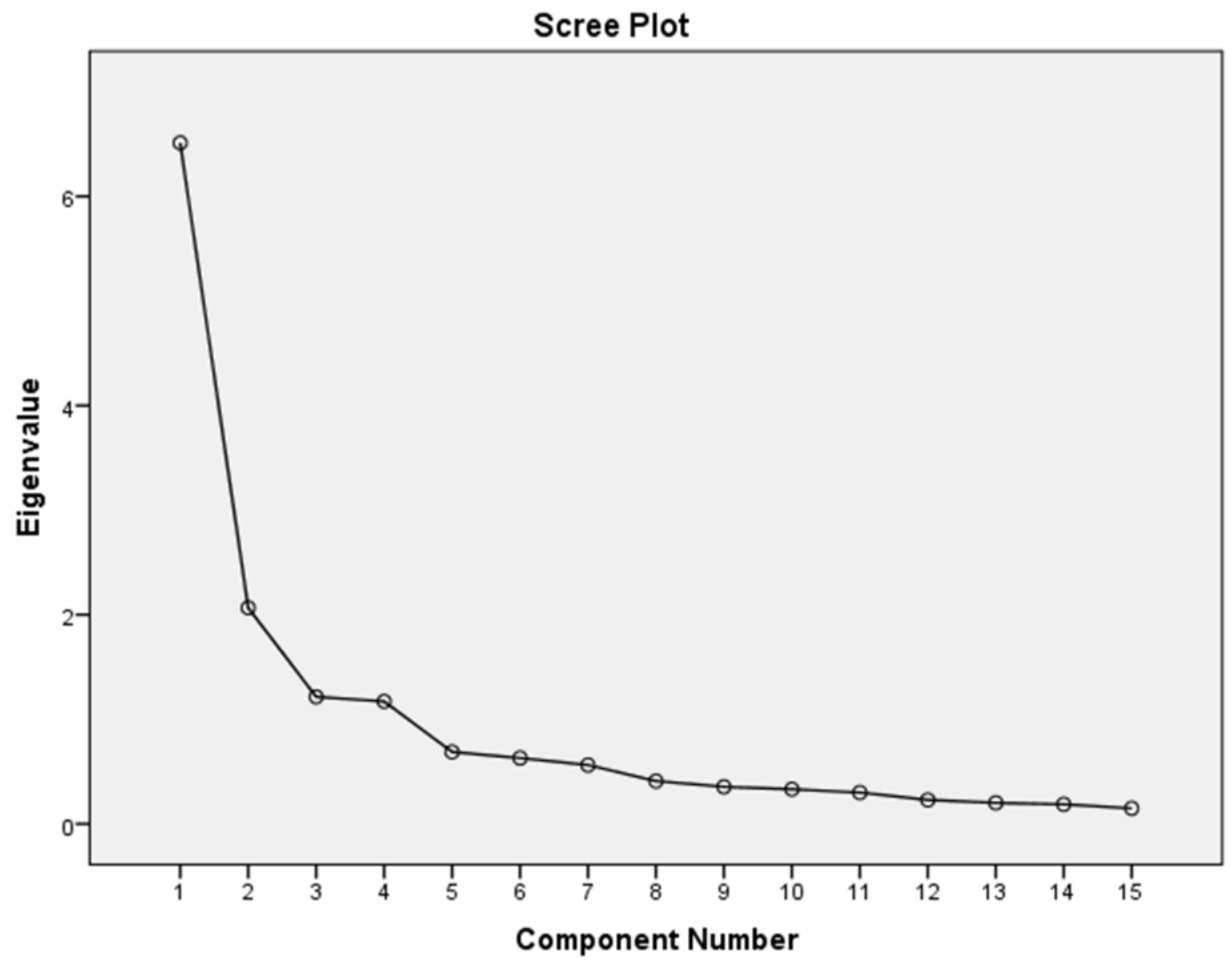

A maximum of four factors was interpreted to avoid introducing noise into the solution. As stated earlier, each variable needed to load $\geq .50$ on each factor and with communalities of the same magnitude. All loadings exceeded $\geq .50$ on each selected indicator (see Table 1 ) and were theoretically closely aligned with the other items in the subscale. Refer to Table 1 for the ranked 
factor loading for indicators on contextual performance.

Table 1: Ranked factor loading for indicators on executives' ratings on managers' contextual performance $(n=200)$

\begin{tabular}{|c|c|c|c|c|}
\hline \multirow[b]{2}{*}{ Indicators } & \multicolumn{4}{|c|}{ Factors } \\
\hline & $\begin{array}{c}1 \\
\text { Follow }\end{array}$ & $\begin{array}{c}2 \\
\text { Persist }\end{array}$ & $\begin{array}{c}3 \\
\text { Help }\end{array}$ & $\begin{array}{c}4 \\
\text { Endors }\end{array}$ \\
\hline Obeying the rules and regulations of the organization. & .928 & & & \\
\hline Treating organizational property with care. & .825 & & & \\
\hline Adhering to organizational values \& policies. & .813 & & & \\
\hline $\begin{array}{l}\text { Paying attention to announcements, messages, or printed } \\
\text { material about the organization. }\end{array}$ & .665 & & & \\
\hline $\begin{array}{l}\text { Persisting with effort to complete work successfully despite } \\
\text { difficult conditions and setbacks. }\end{array}$ & & .941 & & \\
\hline Demonstrating perseverance and conscientiousness. & & .864 & & \\
\hline Putting extra effort into your job. & & .798 & & \\
\hline $\begin{array}{l}\text { Trying to make the best of the situation, even when there } \\
\text { are problems. }\end{array}$ & & .527 & & \\
\hline Helping others who have been absent. & & & .892 & \\
\hline Helping with heavy work-loads. & & & .854 & \\
\hline Maintaining effective working relationships with co-workers. & & & .652 & \\
\hline Representing the organization favorably to outsiders. & & & & -.863 \\
\hline Demonstrating concern about the image of the organization. & & & & -.821 \\
\hline Working within the organization to effect change. & & & & -.753 \\
\hline Exhibiting a concern for organizational objectives. & & & & -.555 \\
\hline
\end{tabular}

Rotation converged in 11 iterations.

Table 2 provides a factor correlation matrix of the indicators for contextual performance.

Table 2: Contextual performance: Factor correlation matrix $(n=200)$

\begin{tabular}{ccccc}
\hline Factor & $\mathbf{1}$ & $\mathbf{2}$ & $\mathbf{3}$ & $\mathbf{4}$ \\
\hline 1 & 1.000 & & & \\
2 & .250 & 1.000 & & \\
3 & .263 & .419 & 1.000 & \\
4 & -.428 & -.401 & -.390 & 1.000 \\
\hline
\end{tabular}

Table 3 provides the contextual performance factor analysis variables and alpha coefficients.

Table 3: Executives' ratings on managers' contextual performance data reduction by variables $(\mathrm{n}=200)$

\begin{tabular}{lcccccc}
\hline \multicolumn{1}{c}{ Construct } & Original & & \multicolumn{4}{c}{ Retained } \\
& Subscales & $\lambda$ & $\alpha$ & Subscales & $\lambda$ & $\alpha$ \\
\hline Persisting & $40-43$ & 4 & .88 & $40-43$ & 4 & .88 \\
Volunteering & $44-47$ & 4 & .83 & - & - & - \\
Helping & $48-52$ & 5 & .83 & $48-50$ & 3 & .79 \\
Following & $53-56$ & 4 & .87 & $53-56$ & 4 & .87 \\
Endorsing & $57-61$ & 5 & .87 & $58-61$ & 4 & .85 \\
\hline CONTEXTUAL PERFORMANCE & 18 & 18 & & 15 & 15 & \\
\hline
\end{tabular}


Note: $\lambda=$ number of indicators; $\alpha=$ alpha reliabilities.

Task performance

A scale from a 75-item pool of managers' task performance was devised by the researcher from Borman and Brush's (1993) 18-dimension taxonomy of managerial performance, including subscale items developed to measure Organizational Effectiveness and Judgement dimensions. Too many factors are invariably extracted when there is a pool of over 50 items. An initial rotation indicated that there were 16 factors present in the pattern matrix. The final iteration of the Kaiser-Meyer-Olkin measure of sampling adequacy was .873, and the Bartlett test of sphericity was significant, indicating that the data were suitable for further analysis.

Modest sized subsamples are prone to error. Comrey and Lee (1992) considered 150 cases to be adequate for solutions with high loading marker indicators. When developing new scales, it is important to obtain the 'purest' manifest variables possible. Given the large number of variables in the task performance scales, it was necessary to ascertain how the variables could be reduced to smaller underlying dimensions. For this to be achieved, only indicators with loadings of $\geq .60$ were retained for further item and factor reduction, unless there was a strong theoretical reason for retaining them. For the final structure, a target of $\geq .70$ was the predetermined loading for each item to ensure reliable scales and a reduction of noise in data.

An iterative process was used to refine the factor structure of task performance. Considerable culling and combining of indicators was therefore necessary to achieve a postulate of parsimony (Kim and Mueller 1978a, Burke et al. 1989). Culling improved the factor structure and confirmed predicted loadings of indicators on factors. Only theoretically congruent clean, high loading items, that did not cross-load, were retained. A scree plot indicated the existence of four factors for task performance, as shown in Figure 5. 
Figure 5: Scree plot indicators on the executive's ratings on task performance $(n=200)$

\section{Scree Plot}

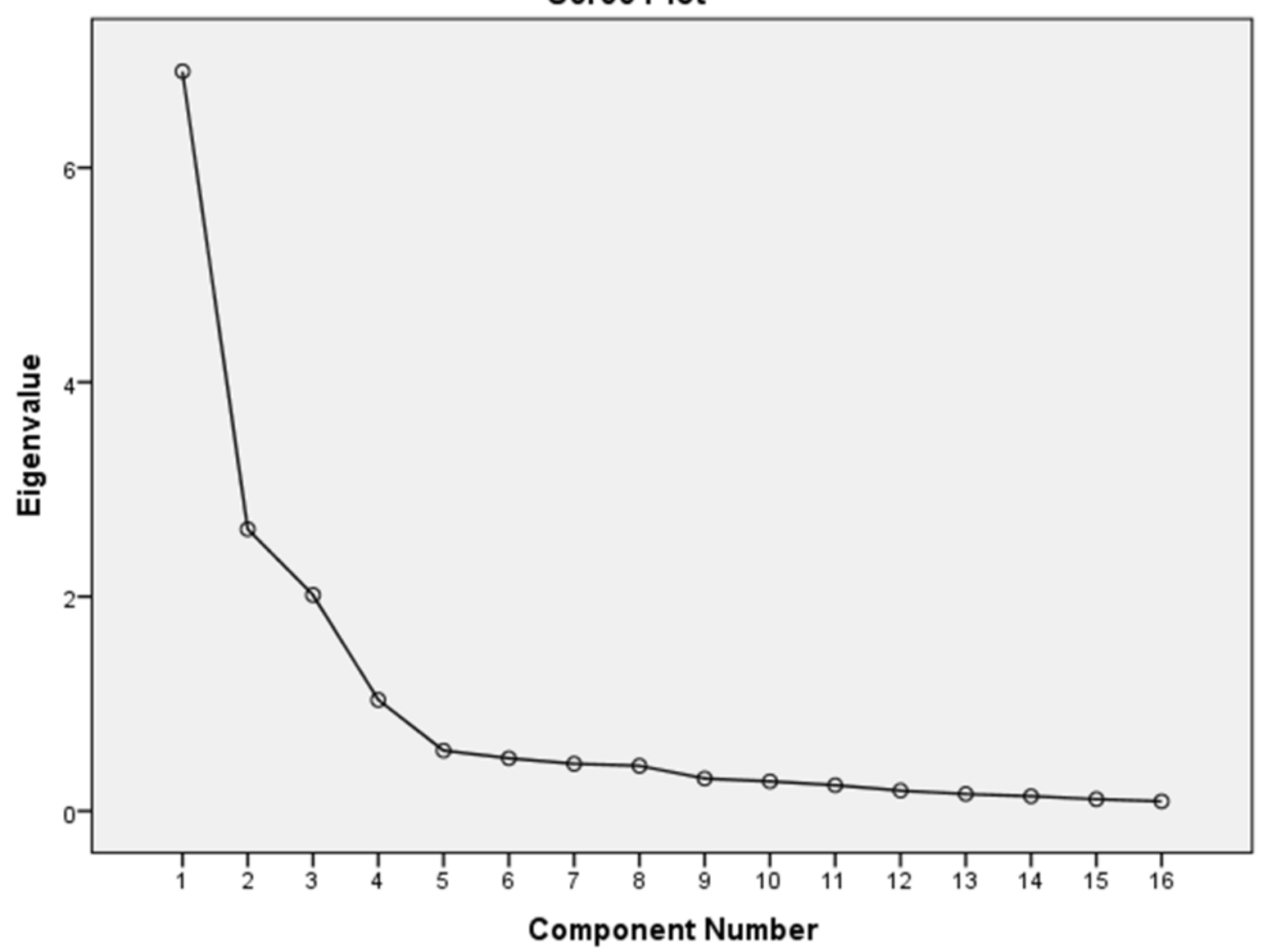

A substantial drop off in the scree plot line was evident after the extraction of the fourth factor. There was a commensurate large drop in total variance for the initial eigenvalues (1.036 to .563) from factor 4 to 5 . Subsequent iterations refined the solution into four meaningful factors represented by 16 high loading indicators. These indicators were intended to be formed into composite scores which exceeded an average of $\geq .70$. Five task performance items were slightly below the $\geq .70$ target but they did not reduce the composite scores below the benchmark for each factor. Four factors emerged from the final iteration: Delegating (4indicators); Technical (4-indicators); Monitoring (4-indicators); Influencing (4-indicators) Only one variable from the 'Monitoring factor' ('Controlling personnel resources') loaded .583 was below the $\geq .70$ target. However, the composite variable score for the 'Monitoring' factor, calculated for the factor, loaded above the threshold of $\geq .70$. 
Table 4: Ranked factor loading and alpha coefficient for indicators on executive's ratings on managers' task performance. Data reduction by variable $(n=200)$

\begin{tabular}{|c|c|c|c|c|}
\hline \multirow[b]{2}{*}{ Indicators } & \multicolumn{4}{|c|}{ Factor } \\
\hline & $\begin{array}{c}1 \\
\text { Delegate }\end{array}$ & $\begin{array}{c}2 \\
\text { Tech }\end{array}$ & $\begin{array}{c}3 \\
\text { Monitor }\end{array}$ & $\begin{array}{c}4 \\
\text { Influence }\end{array}$ \\
\hline Effectively delegating responsibility and authority. & .925 & & & \\
\hline $\begin{array}{l}\text { Avoiding interfering with areas of responsibility delegated } \\
\text { to others. }\end{array}$ & .856 & & & \\
\hline $\begin{array}{l}\text { Delegating authority and responsibility to assist staff's } \\
\text { professional development. }\end{array}$ & .797 & & & \\
\hline $\begin{array}{l}\text { Assigning staff duties and responsibilities consistent with } \\
\text { their abilities as well as the organization's needs. }\end{array}$ & .702 & & & \\
\hline Solving technical problems. & & .913 & & \\
\hline Applying technical expertise. & & .912 & & \\
\hline Providing technical advice to others in organization. & & .866 & & \\
\hline Keeping technically up-to-date. & & .848 & & \\
\hline $\begin{array}{l}\text { Monitoring and overseeing appropriate use of funds within } \\
\text { existing constraints and guidelines. }\end{array}$ & & & .964 & \\
\hline Controlling budgets by allocating funds internally. & & & .941 & \\
\hline Monitoring and overseeing utilization of funds. & & & .940 & \\
\hline Controlling personnel resources. & & & .583 & \\
\hline $\begin{array}{l}\text { Persuading others in the organization to accept your ideas } \\
\text { and position }\end{array}$ & & & & -.947 \\
\hline $\begin{array}{l}\text { Convincing those holding opposing or neutral opinions and } \\
\text { promoting own positions or ideas. }\end{array}$ & & & & -.888 \\
\hline Influencing others inside and outside of the organization. & & & & -.813 \\
\hline Presenting own position clearly and decisively. & & & & -.756 \\
\hline
\end{tabular}

Rotation converged in 8 iterations.

In all, the final structure for task performance was reduced from the predicted 19 factors comprising 75-items, to a 4-factor structure with 16-indicators. A considerable number (59) of indicators were discarded because they failed to achieve loadings necessary to form meaningful factors. Throughout the data reduction process, each subscale was monitored to ensure optimum internal consistency.

Several high loading indicators were evident in both the contextual and task performance subsamples. There were 9 high loading 'marker' variables $(\geq .80)$ for contextual performance, and 12 high loading 'marker' variables for task performance representing a total 21 highloading indicators out of 24 . This indicated that the limits to parsimony for this matrix had been reached. Table 4 shows the intercorrelations among the four factors, for the ranked magnitude of loadings.

Table 5: Task performance: Factor correlation matrix $(n=200)$

\begin{tabular}{ccccc}
\hline Factor & $\mathbf{1}$ & $\mathbf{2}$ & $\mathbf{3}$ & $\mathbf{4}$ \\
\hline 1 & 1.000 & & & \\
2 & .166 & 1.000 & & \\
3 & .332 & .233 & 1.000 & \\
4 & -.581 & -.351 & -.438 & 1.000 \\
\hline
\end{tabular}

Summary of factor analysis of managers' performance scales

Factor analysis was used to empirically establish the dimensionality of the manager's job 
performance variables. Factorial independence was established as each indicator loaded highly on a single factor. Four factors and 16 indicators fitted four of the dimensions of Borman and Motowidlo's (1997) taxonomy of managers' contextual performance. Likewise, 4-factors and 16-indicators $\alpha \geq .89$ fitted 4 of the dimensions of Borman and Brush's (1993) taxonomy of managers' task performance. Task performance indicators and alpha coefficients are presented in Table 6.

Table 6: Ranked factor loading and alpha coefficient for indicators on executive's ratings on managers' task performance. Data reduction by variable $(n=200)$

\begin{tabular}{lcccccc}
\hline \multicolumn{1}{c}{ Construct } & $\begin{array}{c}\text { Original } \\
\text { Subscales }\end{array}$ & $\boldsymbol{\lambda}$ & $\boldsymbol{\alpha}$ & $\begin{array}{c}\text { Retained } \\
\text { Subscales }\end{array}$ & $\boldsymbol{\lambda}$ & $\boldsymbol{\alpha}$ \\
\hline Planning & $62-66$ & 5 & .75 & & & \\
Guiding & $67-69$ & 3 & .80 & & & \\
Training & $70-73$ & 4 & .87 & & & \\
Communicating & $74-77$ & 4 & .84 & & & \\
Representing & $78-81$ & 4 & .74 & & & \\
Technical & $\mathbf{8 2 - 8 5}$ & $\mathbf{4}$ &. $\mathbf{9 1}$ & $\mathbf{8 2 - 8 5}$ & $\mathbf{4}$ &. $\mathbf{9 1}$ \\
Administrating & $86-88$ & 3 & .84 & & & \\
Maintaining & $89-92$ & 3 & .84 & & & \\
Coordinating & $93-96$ & 4 & .80 & & & \\
Deciding & $97-101$ & 5 & .86 & & & \\
Staffing & $102-105$ & 4 & .80 & & & \\
Persisting & $106-108$ & 3 & .82 & & & \\
Handling & $109-112$ & 4 & .87 & & & \\
Committing & $113-116$ & 4 & .81 & & \\
Monitoring & $\mathbf{1 1 7 - 1 2 0}$ & $\mathbf{4}$ &. $\mathbf{9 2}$ & $\mathbf{1 1 7 - 1 2 0}$ & $\mathbf{4}$ &. $\mathbf{9 2}$ \\
Delegating & $\mathbf{1 2 1 - 1 2 4}$ & $\mathbf{4}$ & $\mathbf{. 8 9}$ & $\mathbf{1 2 1 - 1 2 4}$ & $\mathbf{4}$ & $\mathbf{. 8 9}$ \\
Influencing & $\mathbf{1 2 5 - 1 2 8}$ & $\mathbf{4}$ &. $\mathbf{9 0}$ & $\mathbf{1 2 5}-\mathbf{1 2 8}$ & $\mathbf{4}$ &. $\mathbf{9 0}$ \\
Data & $129-132$ & 4 & .90 & & & \\
Contributing & $133-137$ & 5 & .88 & & & \\
\hline TASK PERFORMANCE & $\mathbf{2 . 2 3 - 9 8}$ & $\mathbf{7 5}$ & & & $\mathbf{1 6}$ & \\
\hline
\end{tabular}

Note: $\lambda=$ number of indicators, $\alpha=$ alpha reliabilities.

\section{Methodological issues and limitations}

\section{Constrained sampling frame}

The sampling frame was constrained to managers from organizations based in Western Australia. A larger, more diverse sample would have improved the statistical power of the study. Common performance rating errors (e.g., central tendency, halo effect, harshness, extreme bias and leniency error) were minimised in the design of the questionnaire and administration of the instrument, as recommended by Noe et al. (1994). As Wright and Staw (1999, p. 18) noted, "seldom is behavior objectively measured, and even when it is, the measures may not tap what actually contributes to organizational effectiveness". There are substantial difficulties in monitoring the work output of managers that affects their performance. Measuring managers' performance, in an organizational context, would require data to be collected over many years and at several time intervals. Individual and organizational level variables of managers' performance have typically been measured simultaneously, making it difficult to discern a psychologically meaningful period for this construct to be measured. Typically, performance ratings are infrequent events intended to reflect work undertaken over many months, or even years.

\section{Cross-sectional design}

Longitudinal studies are a way of reducing the limitations inherent in cross-sectional studies, 
such as the empirical validation of causal inferences (Frese \& Zapf in Cooper and Payne 1988). Generally, longitudinal designs are preferred to cross-sectional research designs, because they are believed to have the capacity to examine causal relationships between work outcomes (Randall 1990). However, longitudinal research designs do not necessarily ensure the establishment of causal relationships (Meyer and Allen 1997), or empirical causal sequencing of effects (Kelloway and Barling 1991), or necessarily add greatly to an understanding of how behavioral causes originate (Cooper and Payne 1988). Longitudinal designs do not assist in accounting for the phenomenon of ratees (i.e., executives) rating participants (i.e., managers) higher on contextual performance, simply because they like the ratees (Organ and Paine 1999). Likeability of ratees, introduces another distortion when rating contextual performance. People tend to like positive people. A more constrained definition of halo effects may explain how interpersonal attraction may influence performance assessments. Possibly, the contextual performance antecedent is indicative of superiors' appreciation of 'lack of complaining'. Longitudinal studies are prone to contamination by measurement error. Thus, a cross-sectional approach is acceptable for exploratory studies.

\section{Multirater and multisource assessment versus self-assessment}

Reliable and objective measures of managers' performance were important for this study. Performance measures are notoriously value-laden, especially when self-assessment is used. This has resulted in a growing preference, in the literature and practice, for the use of multiple perspectives of performance. Multisource performance feedback is based on the assumption, derived from measurement theory, that observations of individuals, made from multiple sources, will result in more accurate assessments of individual performance (Church and Bracken 1997). There are potential gains in accuracy when using multisource ratings of managers' performance. However, this preference for multisource assessment needs to be balanced against the pragmatics of implementing such methodology with organizations that are inexperienced with the process.

\section{Future statistical analysis}

An exploratory factor analysis was used in this study to identify the items that formed the factors of executives' perceptions of managers' job performance. As Byrne (1994) concluded, factor analyses are incapable of determining or evaluating error, and therefore are incapable of proposing alternative models to evaluate. Thus, it was not possible to confirm the structure of contextual and task performance dimensions. Future researchers might consider testing a measurement model of managers' job performance to differentiate the structure of managers' contextual and task performance domains in order to confirm the multivariate nature of the construct. Establishing if executives' ratings are a more reliable measure of managers' performance requires advanced confirmatory statistical techniques including multigroup analyses, and the biasing effect of method to measure the substance and structure of managers' job performance. Such analysis would determine the precise structure of the contextual and task performance. An invariance subscale analysis of the indicators and factors is required to establish, validate and cross-validate a measurement model of managers' performance to establish if the construct managers' performance is generalizable across employment groups.

\section{Discussion and conclusion}

Research into managers' performance has been limited by the absence of a common measure to assess the construct. There are widely divergent opinions in the literature about what constitutes valid measures of managers' performance in an organizational context. Measuring managers' performance in order to make comparisons between managers from different domains and firms is methodologically difficult (Murphy 1990), as managerial work is highly 
complex and contingent (Pettigrew and Whipp 1991, Stewart 1989, Hales 1986). Hence, there is need to develop a more specific and comprehensive measure of a manager's job performance.

To this end, Tett et al. (2000) was joined by others (such as Dierdorff et al. 2009) in calling for more specific theory-driven predictive investigations to better understand managerial behavior. A content validation of a 'hyperdimensional' taxonomy of managerial competencies by Tett et al. (2000), derived from the earlier models, was content validated by expert reviewers to yield 53 managerial competencies and definitions of managerial competency framework and 65 performance dimensions within practitioners' taxonomies. Using parallel analysis and factor loadings on US Department of Labor's Occupational Information Network (O*NET) metadata, Dierdorff et al (2009) identified 18 distinct job requirements fundamental to performing managerial roles. These broad requirements were found to underpin the behaviourbased requirements of managerial work roles by 52 managerial occupations, indicated by four factors trait-based managerial work role requirements (Learning, Motivation, and Leadership; Interpersonal Orientation; Conscientiousness; and Generative Thinking [e.g., Creative Thinking]).

As mentioned earlier, only four credible meta-studies have been recently been conducted into the role requirements of managers (Tett et al. 2000, Borman and Brush 1993, Dierdorff et al. 2009, Conway 1999). None of these studies have provided items suitable for testing in the field. Conceptual indicators, and emerging empirical evidence, suggest that the contextual and task performance domains are distinct. Managers' job performance is conceived and explained in the literature as being comprised of both contextual and task performance dimensions, although they are not mutually exclusive (Motowidlo et al. 1997, Borman and Motowidlo 1997, Borman and Brush 1993, Borman and Motowidlo 1993). Managers' contextual performance is an aspect of job behavior, besides formal job requirements, that contributes to organizational effectiveness. Notably, contextual performance also contributes to organizations' effectiveness, and is of particular relevance to these domains of managers' performance, and should therefore be incorporated into appraisals of their performance.

A contribution of this research was to measure the managers' job performance construct. Borman and Brush's (1993) 18 mega-dimension taxonomy of managers' contextual and task performance, coincidently the same as, Dierdorff et al (2009), provided a basis for the development of an instrument to measure managers' performance that is supported by the literature. This was made on the assumption that managers' performance consists of two multidimensional components: contextual performance and task performance. Contextual performance scales were sourced from existing items in the literature, whereas the researcher developed the task performance variables. There was a strong case for developing a robust instrument to measure both managers' contextual and task performance based on Borman and Brush (1993), and Borman and Motowidlo’s (1997) taxonomy.

Executives' (supervisors') ratings of managers' performance had only a modest method variance and were therefore a reliable measure of managers' objective performance. The factor analysis indicated that the construct of managers' performance was multidimensional. Managers' performance dimensions were confirmed to be multivariate and to consist of eight distinct dimensions. Four contextual performance dimensions (Following, Persisting, Helping, Endorsing) and four task performance dimensions (Delegating, Technical, Monitoring, Influencing) formed the scales for the managerial activities. Indicators forming these scales were deemed to be of most consequence to executives.

Issues surrounding judgement, communications and ethics are some of the soft skills needed by contemporary managers. Different types of leadership values, beliefs and styles adopted by managers are likely to be identified from contextual job performance ratings. In this conceptualisations, managing consists of a 'facilitating activity' where contemporary exponents "have to lead better, so that others can know better and therefore act better ... so as 
to bring out the best in other people” (Mintzberg 2004). Ethical managerial and leadership is a crucial aspect of transformational leadership. Effective leadership depends not only on competence but on the managers' ethical conduct used to transform employees (Resick et al. 2006). Ethical leaders extend trust to workers by creating the circumstances required to empower employees. Employers who are perceived to treat employees fairly increase the chances of invoking desired social exchange and the norm of reciprocity (Organ 1990), in the form of citizenship behavior.

Further, an investigation is justified to establish the effect of counterproductive behaviors of transformational leadership on followers. This would lead to better understanding and articulation of the relationship between transformational leadership across the criterion space of individual managers' contextual job performance. Transformational leader behaviors affects followers' trust in leader, satisfaction, and organizational citizenship behavior (Podsakoff et al. 1990) by acting as mentors and role models who subjugate their own interests by increasing the sense of collective unity and purpose. As such, transformational leaders contribute to organizational performance by creating positive organizational climates, systems, and strategies, to create productive work environments (Jung et al., 2003; Liao \& Chuang, 2007). Transformational leadership theory also suggests that it influences performance above and beyond the effect of transactional leadership (Bass 1985, Bass and Avolio 1993). Overall, transformational leadership is positively related to contextual performance (Wang et al. 2011). An important area of future research suggested by Wang, Oh, Courtright and Colbert (2011) is the role of counterproductive work behaviors that influence managers' job performance.

'Influencing' is a rapidly expanding field of psychological inquiry dedicated to establishing the principles that determine beliefs, create attitudes, and move people to agreement and action. Influencing is consistently associated with individual, group, and organization ratings and conceptualisations of managerial/leader job performance. Influencing others to get things done is critical to leading and managing how to collaborate and engaging the emotions of employees to achieve the outcomes (Cullen cited in Barker and Coy 2005 ). Mastering the process of influencing is central to such a notion of leadership, to ensure the 'followers' in organizations are committed to the leader's goals and are committed to work together to achieve positive organizational outcomes. This goes to the essence of ethical consequences of transformational leadership theory.

Research into influencing has examined the judgement and decision-making processes that motive people to efficiently change in positive directions. Cialdini (1993) provided reasons why people are convinced to negotiate and comply with requests in business settings. Research into persuasion has demonstrated how sensitively selected influence strategies have the power to convince others in the workplace (Varghese 2004). In this context it is worth noting that choices made about the use of expressions, content and placement of ideas contribute to persuading others.

Findings from this study have considerable relevance for the development of key HRM strategies and processes, including the attraction and selection of managers (job design, recruitment and selection); management development and career enhancement programs; performance review and associated rewards systems. Both components of managerial performance deserve serious consideration by HRM professionals, and given global trends, contextual performance is likely to become increasingly recognised as important to organizations, and should be incorporated into all HRM processes focused on the attraction, selection and development of managers. As Bartram (2005, p. 1201) suggested, "HRM practitioners need to adopt more differentiated (performance) appraisal tools.” Instruments designed to rate managers' performance should encompass items designed to measure both contextual and task performance, especially domains of influencing and transformative leadership. There is universal recognition in the literature that the context of work shapes 
behavior. With the notable exception of Dierdorff et al (2009) and Hammer and Turk (1987), there is a lack of empirical studies into how different work contexts form managerial behavior. Dierdorff et al (2009) have made a compelling case for including the diverse contexts of managerial work when considering the impact of role enactment. This finding calls into question the appropriateness of standardised performance appraisals for managers as "common managerial role requirements are likely to vary across different managerial occupations" (Dierdorff et al. 2009, p. 975). There is a case for documenting and rewarding and/or punishing variations in different roles when undertaking managers' performance appraisals. This goes the question of how to promote, measure and reward managers' ethical leadership? Future research could model the context of managerial work by linking it to role requirements to predict managerial success. 


\section{References}

Aamodt, M. G. (2013), Industrial/Organizational Psychology: An Applied Approach, Cengage.

Bandura, A. (1977), Social Learning Theory, Englewood-Cliffs, New Jersey: Prentice-Hall.

Bandura, A. (1986), The Social Foundations of Thought and Action, Englewood Cliffs, New Jersey: Prentice-Hall.

Barker, C. and Coy, R., eds. (2005), Understanding influence for leaders at all levels, Sydney, NSW: Australian Institute of Management, McGraw-Hill.

Bartlett, M. S. (1950), “Tests of significance in factor analysis”, British Journal of Psychology, Vol. (Statistical Section) 3 No., pp. 77-85.

Bartram, D. (2005), “The great eight competencies: A criterion-centric approach to validation”, Journal of Applied Psychology, Vol. 90 No. 6, pp. 1185-1203.

Bass, B. M. (1985), Leadership and performance beyond expectations, New York: New York: Free Press.

Bass, B. M. and Avolio, B. J. (1993), "Transformational leadership: A response to critiques" in Ayman, M. M. C. R., ed. Leadership theory and research: Perspectives and directions, San Diego: CA: Academic Press, pp. 49-80.

Bennis, W. and Nanus, B. (1985), Leaders: The Strategies for Taking Charge, New York: Harper \& Row.

Bernardin, H. J. and Beatty, R. (1984), Performance Appraisal: Assessing Human Behaviour at Work, Boston, Massachusetts: Kent Publishing Company.

Borman, W. C. and Brush, D. H. (1993), "More progress toward a taxonomy of managerial performance requriements”, Human Performance, Vol. 6 No. 1, pp. 1-21.

Borman, W. C. and Motowidlo, S. J. (1993), "Expanding the criterion domain to include elements of contextual performance" in Schmitt, N., Borman, W. C. and Associates, eds., Personnel Selection in Organizations, San Francisco, California: Jossey-Bass, pp. 71-98.

Borman, W. C. and Motowidlo, S. J. (1997), "Task performance and contextual performance: The meaning for personnel selection research”, Human Performance, Vol. 10 No. 2, pp. 99-109.

Boudreau, J. and Ramstad, P. (2009), “HR's evolution”, HR Monthly, 34.

Boyatzis, R. E. (1982), The Competent Manager: A Model for Effective Performance, New York: Wiley. 
Burke, M. J., Brief, A. P., George, J. M., Roberson, L. and Webster, J. (1989), "Measuring affect at work: Confirmatory analyses of competing mood structures with conceptual linkages to cortical regulatory systems”, Journal of Personality and Social Psychology, Vol. 57 No. 6, pp. 1091-1102.

Burrell, G. and Morgan, G. (1979), Sociological Paradigms and Organizational Analysis, London, United Kingdom: Heinemann.

Butler, P. and McEvoy, G. (2012), "Strategic human resource management and performance: sharpening line of sight”, HRM Review, Vol. 22 No., pp. 43-56.

Byrne, B. M. (1994), "Testing for factorial validity, replication and invariance of a measurement instrument: A paradigmatic application based on the Maslach Burnout Inventory”, Multivariate Behavioral Research, Vol. 29 No. 3, pp. 489-507.

Cammock, P., Nilakant, V. and Dakin, S. (1995), "Developing a lay model of managerial effectiveness: A social constructionist perspective”, Journal of Management Studies, Vol. 32 No. 4, pp. 443-474.

Campbell, J. P. (1991), "The role of theory in industrial and organizational psychology" in Dunnette, M. D. and Hough, L. M., eds., Handbook of Industrial and Organizational Psychology, 2nd ed., Palo Alto, California: Consulting Psychologists Press, pp. 180186.

Campbell, J. P. (1996), “Group differences and personnel decisions: Validity, fairness, and affirmative action”, Journal of Vocational Behavior, Vol. 49 No. 2, pp. 122-158.

Campbell, J. P., Dunnette, M. D., Lawler III, E. E. and Weick, K. E., Jr (1970), Managerial Behavior, Performance and Effectiveness, New York: McGraw-Hill.

Campbell, J. P., Gasser, M. and Oswald, F. (1996), "The substantive nature of job performance variability” in Murphy, K., ed. Individual differences and behavior in organizations, Hillsdale, New Jersey: Erlbaum, pp. 258-299.

Carlopio, J., Andrewartha, G. and Armstrong, H. (1995), Developing Management Skills: A comprehensive Guide for Leaders, South Melbourne, Victoria: Pearson Education Australia.

Church, A. H. and Bracken, D. W. (1997), "Advancing the state of the art of 360-degree feedback: Guest editors comments on the research and practice of multi-rater assessment methods”, Group \& Organization Management, Vol. 22 No. 2, pp. 149161.

Cialdini, R. B. (1993), Influence: The Psychology of Persuasion, New York: Morrow.

Comrey, A. L. and Lee, H. B. (1992), A First Course in Factor Analysis, 2nd ed., Hillsdale, New Jersey: Erlbaum.

Conway, J. M. (1999), "Distinguishing contextual performance from task performance for managerial jobs”, Journal of Applied Psychology, Vol. 84 No. 1, pp. 3-13. 
Cooper, C. L. and Payne, R., eds. (1988), Causes, Coping and Consequences of Stress at Work, Chichester, New York: Wiley.

Cronbach, L. J. (1984), Essentials of Psychological Testing, 4th ed., New York: Harper \& Row.

Dawis, R. V. and Lofquist, L. H. (1984), A Psychological Theory of Work Adjustment: An Individual-Differences Model and Its Application, Minneapolis, Minnesota: University of Minnesota Press.

Dawis, R. V. and Lofquist, L. H. (1993), "From TWA to PEC", Journal of Vocational Behavior, Vol. 43 No. 1, pp. 113-121.

De Cuyper, N., de Jong, J., De Witte, H., Isaksson, K., Riggotti, T. and Schalk, R. (2008), "Literature Review of Theory and Research on the Psychological Impact of Temporary Employment : Towards a Conceptual Model”, International Journal of Management Reviews, Vol. 10 No. 1, pp. 25-51.

De Vader, C. L., Bateson, A. G. and Lord, R. G. (1986), “Attribution theory: A meta-analysis of attributional hypotheses” in Locke, E. A., ed. Generalizing from Laboratory to Field Settings, Lexington, Massachusetts: Lexington Books, pp. 63-81.

Dierdorff, E. C., Rubin, R. S. and Morgeson, F. P. (2009), "The milieu of managerial work: An integrative framework linking work context to role requirements”, Journal of Applied Psychology, Vol. 94 No. 4, pp. 972-988.

Dyne, L. V. and Ang, S. (1998), “Orgnizational Citizenship Behaviour of contingent workers in Singapore”, Academy of Management Journal, Vol. 41 No. 6, pp. 692-703.

Fabrigar, L. R., Wegener, D. T., MacCallum, R. C. and Strahan, E. J. (1999), "Evaluating the use of exploratory factor analysis in psychological research”, Psychological Methods, Vol. 4 No. 3, pp. 272-299.

Fayol, H. (1916), Administration Industrielle et Generale, Paris, France: Dunod.

Fayol, H. (1949), General and Industrial Administration, New York: Pitman.

Flanagan, J. C. (1951), “Defining the requirements of the executive's job”, Personnel, Vol. 28 No., pp. 28-35.

Flanagan, J. C. (1954), “The critical incident technique”, Psychological Bulletin, Vol. 51 No. 4, pp. 327-358.

Gioia, D. A. and Pitre, E. (1990), "Multiparadigm perspectives on theory building”, Academy of Management Review, Vol. 15 No. 4, pp. 584-602.

Guest, D. (2011), “HRM and performance: Still searching for some answers”, HRM Journal, Vol. 21 No. 1, pp. 1-13. 
Guion, R. M. (1991), "Personnel assessment, selection and placement” in Dunnette, M. D. and Hough, L. M., eds., Handbook of Industrial and Organizational Psychology, 2nd ed., Palto-Alto, California: Consulting Psychologists Press, pp. 327-398.

Hair, J. F., Anderson, R. E., Tatham, R. L. and Black, W. C. (1995), Multivariate Data Analysis with Readings, 4th ed., New York: Maxwell Macmillan International.

Hales, C. P. (1986), "What do managers do? A critical review of the evidence", Journal of Management Studies, Vol. 23 No. 1, pp. 88-115.

Hammer, T. H. and Turk, J. (1987), "Organizational determinants of leader behavior and authority”, Journal of Applied Psychology, Vol. 72 No. 2, pp. 674-68.

Hart, S. L. and Quinn, R. E. (1993), "Roles executives play: CEOs, behavioral complexity and firm performance”, Human Relations, Vol. 46 No. 5, pp. 543-574.

Hemphill, J. K. (1959), “Job description for executives”, Harvard Business Review, Vol. 37 No. 5, pp. 55-67.

Hinkin, T. R. (1995), “A review of scale development practices in the study of organizations”, Journal of Management, Vol. 12 No. 5, pp. 967-988.

Holmes-Smith, P. (1998), Introduction to Structural Equation Modelling Using LISREL and AMOS, Brisbane, Queensland: School Research, Evaluation, and Measurement Services.

Hosie, P. and Sevastos, P. (2007), “Australian managers and the 'happy-performing managers' proposition”, Journal of Human Values, Vol. 13 No. 2, pp. 151-176.

Johnson, J. W. (2001), "The relative importance of task and contextual performance dimensions to supervisor judgments of overall performance”, Journal of Applied Psychology, Vol. 86 No. 5, pp. 984-996.

Johnston, R. (1979), Work and Industrial Relations, Perth, Western Australia: Finn and Collins.

Jones, G. R. (1995), Organizational theory: Text and cases, Reading, Massachusetts: AddisonWesley.

Karambayya, R. (1990), “Contexts for organization citizenship behavior: Do high performing and satisfying units have better 'citizens'”, paper presented at Schulich School of Business, Toronto, Ontario,

Karpin, D. (1995), Enterprising Nation: Renewing Australia's Managers to Meet the Challenges of the Asia-Pacific Century, Canberra, Australian Capital Territory: Industry Task Force on Leadership and Management Skills: Australian Government Printing Service.

Kelloway, K. E. and Barling, J. (1991), “Job characteristics, role stress and mental health”, Journal of Occupational Psychology, Vol. 64 No. 4, pp. 291-304. 
Kim, J. and Mueller, C. W. (1978a), Factor Analysis: Statistical Methods and Practical Issues, Beverly Hills, California: Sage Publications.

Kim, J. and Mueller, C. W. (1978b), Introduction to Factor Analysis: What It is and How to Do It, Beverly Hills, California: Sage Publications.

Kline, P., ed. (1994), An Easy Guide to Factor Analysis, New York.

Kotter, J. (1982), The General Managers, New York: Free Press.

Luthans, F., Rosenkrantz, S. A. and Hennessey, H. W. (1985), "What do successful managers really do? An observation study of managerial activities", The Journal of Applied Behavioral Science, Vol. 21 No. 3, pp. 255-270.

Luthans, F., Welsh, D. H. and Lewis, A. T. (1988), "A descriptive study of managerial effectiveness”, Group \& Organization Studies, Vol. 13 No. 2, pp. 148-162.

MacKenzie, S. B., Podsakoff, P. M. and Fetter, R. (1991), "Organisational citizenship behaviour and objective productivity as determinants of managerial evaluations of salespersons' performance”, Organizational Behavior and Human Decision Processes, Vol. 50 No., pp. 123-150.

Martinko, M. J. and Gardner, W. L. (1990), "Structured observation of managerial work: A replication and synthesis”, Journal of Management Studies, Vol. 27 No. 3, pp. 329-357.

McClelland, D. (1985), Human Motivation, Glenview, Illinois: Scott Foresman Publishers.

Meyer, J. P. and Allen, N. J. (1997), Commitment in the Workplace: Theory, Research and Application, Thousand Oaks, California: Sage.

Mintzberg, H. (1973), The Nature of Managerial Work, Harper Row.

Mintzberg, H. (2004), Managers not MBAs: A Hard Look at the Soft Practice of Managing and Management Development, San Francisco. California: Berrett-Koehler.

Model, S. (2005), "Triangulation between case study and survey methods in management accounting research: An assessment of validity implications ", Management Accounting Research, Vol. 16 No. 2, pp. 231-254.

Morgan, G. and Smircich, L. (1980), “The case of qualitative research", Academy of Management Review, Vol. 5 No. 4, pp. 491-500.

Morse, J. J. and Wagner, F. R. (1978), "Measuring the process of managerial effectiveness”, Academy of Management Journal, Vol. 21 No. 1, pp. 23-35.

Motowidlo, S. J. (2000), "Some basic issues related to contextual performance and organizational citizenship behavior in human resource management”, Human Resource Management Review, Vol. 10 No. 1, pp. 115-126. 
Motowidlo, S. J., Borman, W. C. and Schmit, M. J. (1997), “A theory of individual differences in task and contextual performance”, Human Performance, Vol. 10 No. 2, pp. 71-83.

Motowidlo, S. J. and Schmit, M. J. (1999), "Performance assessment in unique jobs" in Llgen, D. R. and Pulakos, E. D., eds., The Changing Nature of Performance, San Francisco: Jossey-Bass, pp.

Motowidlo, S. J. and Van Scotter, J. R. (1994), "Evidence that task performance should be distinguished from contextual performance”, Journal of Applied Psychology, Vol. 79 No. 4, pp. 475-480.

Murphy, K. R. (1990), “Job performance and productivity” in Murphy, K. R. and Saal, F. E., eds., Psychology in Organizations: Integrating Science and Practice, Hillside, New Jersey: Lawrence Erlbaum Associates, pp.

Nankervis, A., Baird, M., Coffey, J. and Shields, J. (2013), "Human Resource Management: Strategy and Practice”, 8(

Neal, A. and Griffin, M. A. (1999), "Developing a model of individual performance for human resource management”, Asia Pacific Journal of Human Resources, Vol. 37 No. 2, pp. 44-59.

Noe, R. A., Hollenbeck, J. R., Gerhart, B. and Wright, P. M. (1994), Human Resource Management: Gaining a Competitive Advantage, 1st ed., Chicago, Illino is: Irwin.

Organ, D. W. (1988), Organizational Citizenship Behavior: The Good Soldier Syndrome, Lexington, Massachusetts: Lexington Books.

Organ, D. W. (1990), “The motivational basis of organizational citizenship behavior", Research in Organizational Behavior, Vol. 12 No., pp. 43-72.

Organ, D. W. (1997), “Organizational citizenship behavior: It's construct clean-up time”, Human Performance, Vol. 10 No. 2, pp. 85-97.

Organ, D. W. and Paine, J. (1999), “A new kind of performance for industrial and organizational psychology: Recent contributions to the study of organizational citizenship behavior" in Cooper, C. L. and Robertson, I. T., eds., International Review of Industrial and Organizational Psychology, Chichester, New York: Wiley, pp. 338368.

Organ, D. W. and Ryan, K. (1995), “A meta-analytic review of attitudinal and dispositional predictors of organizational citizenship behavior”, Personnel Psychology, Vol. 48 No. 4, pp. 775-802.

Pearce, J. L. (1993), "Toward an organizational behavior of contract laborers: Their psychological involvement and effects on employee co-workers”, Academy of Management Journal, Vol. 36 No., pp. 1082-1096.

Pettigrew, A. and Whipp, R. (1991), Managing Change for Competitive Success, Oxford, United Kingdom: Blackwell. 
Pfeffer, J. (1982), Organizations and Organization Theory, Boston, Massachusetts: Pitman.

Ployhart, R. E., Wiechmann, D., Schmitt, N., Sacco, J. M. and Rogg, K. (2003), “The crosscultural equivalence of job performance ratings”, Human Performance, Vol. 16 No. 1, pp. 49-79.

Podsakoff, P. M., Ahearne, M. and MacKenzie, S. B. (1997), "Organizational citizenship behavior and the quantity and quality of work group performance”, Journal of Applied Psychology, Vol. 82 No. 2, pp. 262-270.

Podsakoff, P. M. and MacKenzie, S. B. (1997), "Impact of organizational citizenship behavior on organizational performance: A review and suggestions for future research”, Human Performance, Vol. 10 No. 2, pp. 133-151.

Podsakoff, P. M., MacKenzie, S. B., Morman, R. H. and Fetter, R. (1990), “Transformational leader behaviors and their effects on followers trust in leader, satisfaction, and organizational citizenship behavior”, The Leadership Quarterly, Vol. 1 No. 2, pp. 107142.

Polivka, A. E. and Nardone, T. (1989), “The definition of contingent work”, Monthly Labor Review, Vol. 112 No., pp. 9-16.

Price, J. L. and Mueller, C. W. (1986), Handbook of Organizational Measurement, Marshfield, Massachusetts: Pitman.

Quinn, J. B. (1992), Intelligent Enterprise, New York: Free Press.

Quinn, R. E., Faerman, S. R., Thompson, M. P. and McGrath, M. R. (1996), Becoming a Master Manager: A Competency Framework, 2nd ed., New York: John Wiley \& Sons.

Randall, D. M. (1990), “The consequences of organizational commitment: Methodological investigation”, Journal of Organizational Behavior, Vol. 11 No. 5, pp. 361-378.

Rao, M. V. H. and Pasmore, W. A. (1989), “Knowledge and interests in organizational studies: A conflict of interpretations”, Organization Studies, Vol. 10 No. 2, pp. 225-239.

Resick, C. J., Hanges, P. J., Dickson, M. W. and Mitchelson, J. K. (2006), “A cross-cultural examination of the endorsement of ethical leadershi”, Journal of Business Ethics, Vol. 63 No., pp. 345-359.

Robertson, I. T., Baron, H., Gibbons, P., MacIver, R. and Nyfield, G. (2000), "Conscientiousness and managerial performance", Journal of Occupational and Organizational Psychology, Vol. 73 No., pp. 171-80.

Rousseau, D. M. (1995), Psychological contracts in organizations: Understanding written and unwritten agreements, CA: Sage: Thousand Oaks. 
Schweizer, K. (1992), “A correlation-based decision-rule for determining the number of clusters and its efficiency in uni-and multi-level data”, Multivariate Behavioral Research, Vol. 27 No. 1, pp. 77-94.

Shetty, Y. K. (1982), "Management’s role in declining productivity”, California Management Review, Vol. 25 No., pp. 33-47.

Steers, R. M. (1975), "Problems in the measurement of organizational effectiveness", Administrative Science Quarterly, Vol. 20 No. 4, pp. 546-558.

Stewart, R. (1989), "Studies of managerial jobs and behaviour: The ways forward”, Journal of Management Studies, Vol. 26 No. 1, pp. 1-10.

Stogdill, R. (1974), Handbook of Leadership: A survey of theory and research, New York: The Free Press (McMillan).

Tabachnick, B. G. and Fidell, L. S. (1996), Using Multivariate Statistics, 3rd ed., New York: HarperCollins.

Tabachnick, B. G. and Fidell, L. S. (2001), Using Multivariate Statistics, 4th ed., New York: Allyn \& Bacon.

Tett, R. P., Guterman, H. A., Bleier, A. and Murphy, P. J. (2000), "Development and content validation of a "hyperdimensional" taxonomy of managerial competence", Human Performance, Vol. 13 No. 3, pp. 205-251.

Tornow, W. W. and Pinto, P. R. (1976), "The development of a managerial job taxonomy: A system for describing, classifying and evaluating executive positions”, Journal of Applied Psychology, Vol. 61 No. 4, pp. 410-418.

Ulrich, D., Brockbank, W., Younger, J. and Ulrich, M. (2013), Global HR Competencies: Mastering competitive value from the outside-in, Michigan: McGraw-Hill.

Van Dyne, L., Cummings, L. L. and McLean-Parks, J. (1995), "Extra-role behaviours: In pursuit of construct and definitional clarity (A bridge over muddied waters)", Research in Organizational Behavior, Vol. 17 No., pp. 215-285.

Van Dyne, L. and Le Pine, J. A. (1998), "Helping and voice extra-role behaviors: Evidence of construct and predictive validity”, The Academy of Management Journal, Vol. 41 No. 1, pp. 108-119.

Varghese, S. A. (2004), "Transforming language into business influence: A tutorial on persuasion”, Education Review of Business Communication, Vol. 7 No. 1, pp. 57-68.

Viswesvaran, C., Schmidt, F. L. and Ones, D. S. (2005), “Is There a General Factor in Ratings of Job Performance? A Meta-Analytic Framework for Disentangling Substantive and Error Influences”, Journal of Applied Psychology, Vol. 90 No. 1, pp. 108-131.

Vroom, V. H. (1964), Work and Motivation, New York: Wiley. 
Wang, G., Oh, I.-S., Courtright, S. H. and Colbert, A. E. (2011), “Transformational leadership and performance across criteria and levels: A meta-analytic review of 25 years of research”, Group \& Organization Management, Vol. 36 No. 2, pp. 223-270.

Williams, R. E. (1956), A description of some executive abilities by means of the critical incident technique, unpublished thesis ( Doctoral Dissertation), Columbia University.

Wright, T. A. and Staw, B. M. (1999), “Affect and favorable work outcomes: Two longitudinal tests of the happy-productive worker thesis”, Journal of Organizational Behavior, Vol. 20 No. 1, pp. 1-23.

Yukl, G. A. (1998), Leadership in Organizations, 4th ed., Upper Saddle River, NJ: Prentice Hall.

Zikmund, W. G. (2002), Business Research Methods, 7th ed., Mason, Ohio: Thompson Learning South-Western. 